\title{
Deradicalization Programs Daliemain the Western States
}

\author{
Emad Al-Hammadin \\ Lit Col (Jordanian Royal Guard) \\ Master of Reasearch in Security and Criminology
}

\begin{abstract}
The war on terror has created more harm than good, largely confronting terrorism with a kinetic approach that has yielded undesirable outcomes. Increased numbers of foreign fighter returnees and home-grown terrorists have forced many countries to develop soft approach deradicalization programs, part of wider Counter Violent Extremism (CVE) initiatives, in response. These programs have been created to manage and deradicalize apprehended violent extremists, often within the correctional setting. Although many countries face the challenges of different forms of radicalization, different states have approached the construction of these programs differently. In the Arab world, the focus is on correcting deviant religious ideology through re-education and the support of normative Islam. In Western countries, on the other hand, there has been more focus on the adoption of social and psychological programs and processes to counter radicalized violent extremists. This study aims to map, for the first time, the Western deradicalization programs in terms of the fundamental assumptions upon which they are based. It will then explore how these assumptions have affected the structure and successof the programs. The research method adopted is an inductive theoretical approach using core qualitative components consisting of case studies and comparative analysis. This research confirms that Western countries generally do not focus on religious perspective in deradicalization programs, although there is significant overlap in how the programs function. It is recommended that a mixture of religious and social approaches, with a focus on ideology, is crucial to success in the future.
\end{abstract}

\section{Introduction}

This article analyses the deradicalization programs in the Western states in terms of underlying assumptions and the scholarship built upon. Finding how these programs are run and operated will contribute to answering the question of why deradicalization programs in Western countries different than Muslim countries?. It argues that Western deradicalization programs are built on varying social and psychological factors such as identity, social inclusion, and group dynamics and choose to lessen religion's role. These assumptions determined the shape and process of the programs.

Three Western countries were chosen as case studies: Australia, the UK, and Denmark. Using multiple case studies will allow more diversity in representing a wide range of deradicalization programs in the Western world (Gustafsson, 2017, p. 179). In addition to geographical areas, these countries have other different aspects that have contributed to the chosen criteria. First, their origins: Britain is Anglo-Saxon, and in Western Europe, Denmark is a Scandinavian country with a different language than the other two, and as well it has a unique program considered by many researchers as successful. Australia is one of the highest contributors (per capita) to foreign fighters from countries outside the Middle East (Levy, 2018). Second, in terms of the population, these countries represent different sizes. The UK has a large population size of 61 million, Australia is a middle size with 25 million, and Denmark is a small size with 6 million. Last, these countries have a diverse cultural, ethnic, religious, and ideological background which can represent, in this study, other Western countries who have the same minorities. In spite of its vital role in countering terrorism, the United States has not been chosen because it simply has no program of deradicalization yet. Although the three countries are of different geographical area, they have been facing almost the same challenges of applying deradicalization programs. However, adopting the same program is not applicable as many researchers have asserted (Rabasa, 2010); it is necessary to understand the strengths and limitations of programs through a compare and contrast process (Koehler, 2017, p. 135).

This chapter is divided into two parts: the first part is the anatomy and analysis of the three countries' programs and the second part is the analysis of the assumptions and the scholarship that these programs are built on. In this chapter, the data was collected from primary resources through examining and evaluating the publicly published government documents for the three countries. In addition, the government and pro-government websites have been closely examined. 
The findings of this article indicate that there are underlying assumptions that missed being implemented in deradicalization programs, which with more examination could be the reason why some deradicalization programs have failed to achieve their goals.

\section{Case Study1}

\section{Australia}

Australia has an average population size compared to other Western countries; however, its density per kilometer is small compared to its vast territory. According to the 2016 census, of its 24 million population, Muslims are $604,000-$ $2.5 \%$ of the population (Australian Bureau of Statistics, 2016). Although Australia had Muslim settlers of Afghani descent since 1880, it was not until 1970 that Australia widely opened its doors for Muslim immigrants and maintained a multiculturalism policy.

\section{Terrorism in Australia}

Recent years have proved that terrorism in Australia is growing. In 2014 prime minister Tony Abbot declared that the number of known Australians who left to fight in Syria and Iraq was 60, then the official figure was doubled in 2015 to reach 120 (Levy, 2018; Barret et al., 2015). In June 2017 Yacqub Khayre killed a man and took a woman hostage in a Melbourne suburb. The police killed Khayre and freed the women after two hours of standoff; ISIS seized the moment and claimed responsibility for this operation. Its propaganda claimed that Khayre is a martyr and the operation was a response to Australian participation in the war on terrorism led by the US. In the same year, ISIS tried to down an Etihad aircraft flying from Sydney to Abu Dhabi, but thanks to information from a foreign country, the plot was foiled (Dredge, 2017).

Furthermore, in 2015, Farhad Jabbar, an ISIS operative, killed a policeman in front of the police department in Parramatta, and later, the police killed him (Ralston, 2017). Before these events, police conducted the largest counterterrorism operation in the country's history called Pendeniss in 2004-05 to arrest several new home-grown Jihadists, as well as the Neath operation which was conducted in 2009 to arrest five people in Melbourne. The terrorists were primarily targeting Holsworthy Barracks in Sydney (Quackenbush, 2017).

These events have a tremendous negativeinfluence on communal harmony. On the one hand, the Muslim minority has perceived these police raids and new anti-terrorism laws as targeting them and making them feel disenfranchised. On the other hand, many Australians start blaming Muslims for terrorism offenses, which leads to an increase in Islamophobia and community division (El-Said, 2015, p. 69). In contrast, a growing body of knowledge has rejected this nationalism and jingoistic approach and questioned the underlying root causes of radicalization.

\section{Deradicalization Efforts}

Although Australia has not yet had a comprehensive program for individual deradicalization, it relies on counter violent extremism programs and supporting community initiatives to address community resilience. To counter violent extremism, Australia is working on two levels - the federal and the state and the two levels should work in a cooperative relationship.

It better before the study delves in the western cast studies to redefine the meaning of the terms deradicalization, disengagement, and counter-radicalization. Deradicalization is a process that fosters an individual to change or abandon their extremist mindset and adopt more mainstream views (Commonwealth of Australia 2011). UN has made clear distinctions between deradicalization and counter-radicalization: it defined the latter as "a package of social, political, legal and educational and economic programs specifically designed to deter disaffected, and possibly already radicalized, individuals from crossing the line and becoming terrorists". Disengagement refers to an individual stepping away from involvement in, or material support for, violence as a method of achieving an ideological, religious or political goal (Commonwealth of Australia 2011; Harris-Hogan \& Barrelle 2014; Nasser-Eddin 2015)

However, for this study, we divide the efforts of counter-radicalization into two parts: in prisons and outside prisons.

\section{In Prisons}

The efforts of deradicalization were started in 2000 by the Victorian police with a basic program in collaboration with the Islamic Council of Victoria (ICV) has been implemented. Although it has remained in its infancy, it grows all the time and is incorporating new elements. As a result, the ICV sends an Imam once or twice a week in collaboration with the prison authority, and the deradicalization takes the form of a series of lectures designed to meet the needs of inmates. This cooperation with an Australian Islamic entity could yield significant mutual benefits. A study by Monash and Australian National University researchers have singled out this program as one of the rare successful deradicalization programs run in the country (Grand \& Urban, 2017). Indeed, Victoria's rehabilitation program is far from being seen as sophisticated as the one in Saudi Arabia in terms of scope and intensity. 
While Victoria was the first to establish deradicalization efforts, New South Wales (Government) is focusing more on CVE initiatives. In its Goulburn prison, part of which is called super-max, all detainees on terrorism charges have been incarcerated.

The prison has a chaplaincy attached to it since it was built in 2003, as part of inmates' rights to have religious counseling, an Imam comes once a month for religious matters, mostly other than deradicalization (El-Said, 2015, p. 90). However, SBS news reported that the government would introduce a deradicalization program for the jailed youth similar to those in adult prisons, after an increase in their numbers in NSW. Although their number is five, the number is expected to increase (SBS News, 2018).

As a result, in 2016, NSW has introduced a new program called Proactive Integrated Support Model (PRISM) aimed at deradicalizing people vulnerable to radicalization and prison inmates who have charged with terrorism-related offenses. Cherny points out that PRISM is the only Australian program targeting individuals at risk of radicalization and after being released. The program starts as early as two years before the release of detainees (Cherney, 2018). It is a team of psychologists and health workers working in close relation with a Muslim Imam. Participation in the program is voluntary, and referrals come from different units within the corrective authorities. This new approach is considered a turning point and gradually departing from the policy of not intervening in the ideology of a minority to more focus on the role of religious content in deradicalization.

Unfortunately, the role of the family is missing in both states; neither Victoria nor NSW has any comprehensive family program to support inmates during or after release. The family is allowed to see their detainee once a week in NSW and allowed to stay one hour or two on the weekends only. But an empirical study from Australia suggests that family and friends could play a significant role: they might help in deradicalizing them and exert pressure to abandon violence or abstain from joining a terrorist group (El-Said \& Harrigan, 2013, p. 90). In prisons also there are no well-structured vocational, educational or training programs to occupy the time of detainees and prepare them for life after prison. Furthermore, none of the two states have a structure of social programs for the integration of detainees after released from prison. The two states have procedures applied to all detainees no matter what the charge is; they inform the prisoners on how to apply for a job after release and how to claim unemployment benefits (El-Said, 2015, p. 94). Victoria has programs called Lecture and Open Discussion forum (LOD) established in 2010 by a joint project between the Islamic Council of Victoria (ICV), Victoria Police, and federal police to target former detainees using a series of lectures conducted in mosques or halls. In this forum, former detainees choose a topic, and an Imam from ICV delivers the lecture followed by an open discussion. However, the latter procedures could not be named as social integration programs because of the casual nature of the lectures. Nevertheless, in the counter-violent strategy and under 'Targeted work with vulnerable communities and institutions' the government has acknowledged that Victoria has a holistic approach to rehabilitation including pre- and post-release components (Parliament of Australia, 2017).

\section{Outside of Prisons}

In 2010, the Australian Attorney-General's Department (AGD) engendered a Counter Violence Extremism task force (Parliament of Australia, 2017). The first mission of this force was to release a report on the gap between research centers and government departments in terms of the knowledge on root causes of terrorism (Department of Home Affairs, 2018). The recommendation to the government was to cooperate with research bodies in researching of various factors that lead to terrorism and find a mechanism for applying these outcomes to the ground incorporating government agencies. The report's finding suggests the government should utilize the academia to enhance the understanding of the extremism. As a result, the counter-violence strategy built on four main paths of activities (Parliament of Australia, 2015).First, 'Building strength in diversity and social participation' - this path aims to prevent the radicalization process from occurring in the first place by addressing societal motivations that lead to disengagement. Second, "Targeted work with vulnerable communities and institutions" - here the government works with state and territory governments to rehabilitate people imprisoned on terrorism-related charges and ensure extremists do not radicalize other inmates. Third, "addressing terrorist propaganda online" - the government pledged to allocate $\$ 18$ million to counter-terrorism propaganda online. This will include establishing social media monitoring and analysis to better understand the trends in online radicalization and recruitment (Brandis, 2015).

Finally, "Diversion and deradicalization" - this stream is the intervention CVE program led by states and territories including funding and coordination. The aim of this stream is designing programs tailored to intervening and engaging with individuals at risk of radicalization. The activity of such aspects is mentoring and coaching, counseling, education, and employment support (Parliament of Australia, 2017).The state of NSW has implemented many programs aimed at increasing community resilience and social cohesion. Although the aim is to address social factors such as community engagement, social inclusion, and community resilience, most of these initiatives included religious content represented by Imams. 
For example, Peer to Peer: Building Capacity and Resilience, and Sharing Humanity programs and others have the lion's share of the budget allocated for CVE, with a total of 50 projects and value of $\$ 7$ million (Akbarzadeh, 2013).

Community Partnership Action (COMPACT) is an NSW program aimed at enhancing cohesion and harmony between the diverse communities in Australia. COMPACT supports initiatives emanating from the people themselves directed at helping and integrating other people into the multicultural society (Affairs, 2018). In addition, in 2009 a program of countering narrative by the Muslim community of NSW has been introduced. Here the Muslim community invited role model Muslims from around the world such as artist's soccer players and politicians to address youth on various topics. The Imams and Mufti of NSW initiated this project; many Muslim scholars had come from around the world, such as Hamza Yousef, Aftab Malik, and John Esposito. Equally important is the Living Safe Together Program aimed at finding activities for local communities to steer them away from violent extremism. It works through non-commercial, non-government and local government partners. These grants are set to help an organization design and develop new, innovative services, build more sustainable capacity in existing services, and refocus existing services to address radicalization (Living Save Together, 2018).

One of the significant aspects of CVE in Australia is the cooperation between the government agencies and the academic community. The government has funded many promising projects in many Australian universities to find out best practice in CVE and deradicalization. Examples of the projects and the host universities in 2016 are Youth Resilience to Violent Extremism (Victoria University), CVE Evaluation (Victoria University), and Establishment of a Network of Civil Society Organizations (Deakin University) (Counter Extremism Project, 2017). Despite this, it is not clear if the government has taken the outcomes of these researches into consideration when planning deradicalization programs.

\section{Successfulness}

Evaluating the impact of deradicalization efforts on communities or detainees in any place is not an easy task. Australian deradicalization efforts are no exception, taking into consideration many aspects. First, the programs such as PRISM are in early stages, and it's too early to judge the effectiveness of these new measures. Second, they are just measures and processes, which have not amounted to fully-fledged programs. Even the Victoria police religious-based measures have not been supported by other non-religious factors such as social and psychological elements (El-Said, 2015, p. 99). Thomas called the Victoria program 'Imams chatting with prisoners' to depict its ineffectiveness. This cooperation has been ended by the Islamic Council of Victoria when it withdrew from this partnership (Pettingera, 2017).

Moreover, the number of released detainees is insignificant, and they are under constant surveillance from police officers. However, recidivism does occur. Yacqub Khayre, for example, was acquitted of his role in a terrorist incident in 2010 and passed a deradicalization scheme; however, he killed a man and took a woman hostage and wounded three officers before being killed (Houston \& Donelly, 2017). Finally, the recidivism rate is challenging to establish, and it is not easy to determine which factors could cause recidivism (El-Said, 2015).

\section{Underlying Rationale}

Various underlying assumptions have influenced deradicalization efforts in Australia. Akbarzadeh asserts that the underlying assumptions of deradicalization programs in Australia are focused on the narrow understanding of Islamic principles by radicals; as a result, the deradicalization has emphasized educating people and teaching them about Islam. However, Akbarzadeh has downplayed the importance of this factor, claiming that other factors have not been considered in line with the religious narrative (Akbarzadeh, 2013). El-Said asserts that religion was not considered in Australia, only a pilot scheme by Victorian police, and it has remained in its infancy (El-Said, 2015, p. 87).Although many programs of CVE emphasize the role of ideology and especially theology in radicalized individuals, there are some underlying reasons that could prevent this from taking place (Butt \& Tuck, 2014). First, many Western countries have distanced themselves from being involved in the religious affairs of its people - the democratic point of view emphasizes the separation of church and state. Second, the sensitivity of stigmatizing some minorities of violent extremism could endanger coexistence between cultures. Finally, the countries that have succeeded in implementing deradicalization programs on a full scale have their people dominated by Muslims. Although the reasons above are valid to some extent, the Western democracies have been involved in one way or another in religious affairs but varying degrees between countries.

Furthermore, Muslims' socio-economic marginalization in Australia, which was not addressed, could lead to more violence and to hinder the deradicalization efforts. The Australian census office points to the discrepancy in terms of homeownership and living standards between Muslim and non-Muslim. The 2011 census data confirms that 2\% of registered Muslims have no income comparing to $1.06 \%$ for non-Muslims (Hassan, 2008). Unfortunately, this was not addressed by the government-released documents and budget. 
Most of the CVE and deradicalization programs target short-range outcomes and have not addressed the root causes of the radicalization process, which makes these programs' influence limited.

Finally, better education on Islam might be the key for CVE - this view is shared between the academic scholars and government officials. The latter has supported research and funded centers in universities to find the reasons for radicalization and best practice to tackle the problem. This indicates the importance of education on Islam, not only for Muslims and Imams but also for the Australian people who need to know more about Muslim minorities (Akbarzadeh, 2013).

\section{Case Study 2}

\section{The UK}

According to the national statistics, the UK population is 66.5 million, with 5\% Muslims (Review, 2018). The UK is one of the countries that have a long history in dealing with terrorism: it has faced the Irish Republican Army (IRA) during the civil war and later both sides signed a peace agreement. In contrast, contemporary terrorism led by ISIS and Al-Qaida shows no compromise. In 2005 the UK came under terrorist attack in the London bombing which shocked law enforcement and the community alike. Although it was partly expected because the Blair government was the most reliable American ally in the war on terror, the casualties were very high and the time and place of the attack were not expected. Before the attack, most of the UK counterterrorism procedures were reactive, but this attack forced counterterrorism efforts to be more proactive. One of these measures which have been missed before is community engagement (Godec, 2017). The idea behind community participation is that prevention is better than cure, or, as Griffith-Dickson terms it, "early intervention" (Gwen Griffith-Dickson et al., 2014). The government has sought the help of the Muslim community and civil society through conducting strategic partnership and engagement on a microlevel. The early intervention strategy needs cooperation between different parts of the community to detect individuals at risk of radicalization and then intervene. However, the response from the Muslim community varied from sincerity to suspicion; as a Muslim said to a police officer, "we cannot be a partner and a suspect at the same time" (Gwen Griffith-Dickson et al., 2014).

\section{Mechanisms}

Countering extremism strategy in the UK was developed according to terrorism growth on the national and international level. In 2003, the Home Office introduced a first Counter-Terrorism Strategy (CONTEST), which came into operation in 2006; the aim was to protect the interests of the country overseas, and the strategy has passed many stages and improvement until 2017. CONTEST has split into four main programs called the 4Ps: Prevent, Pursue, Protect, and Prepare (Government of the UK, 2018).

Prevent is the first and most crucial phase in all of the 4Ps; in this phase, the strategy was built on the notion that the process of deradicalization might happen at short notice, not more than weeks or months, which makes the time of intervention as crucial (Ali, 2015).

Part of the Prevent strategy is a program called Channel; this is multi-coordinated program led by the police. Its main aim is to identify the people who show signs of radicalization or at risk of radicalization, then assess the extent of that risk and determine the most appropriate response procedures or plan to help the individuals involved before the damage is done. Police rely on frontline workers for referral (Godec, 2017). The frontline workers is a wide concept: it comprises police officers, social workers, religious leaders, and teachers, and the latter has the highest proportion of referrals. Workers identify the individuals at risk of extremism and decide if they need an intervention or not. Additionally, the mechanisms used to determine these vulnerabilities are engagement, intent to cause harm, and capacity to cause damage (Ali, 2015).

The Counter-Terrorism and Security Act 2015 (CTSA) has a statutory footing, which means certain bodies have a legal obligation to prevent people from being drawn into any form of radicalization (Godec, 2017). The frontline workers should report any suspicion or sign leading to radicalization or they have to face legal action.

Clearly, the Prevent program has stirred sentiments among minorities and frontline workers alike. Frontline workers such as higher education teachers believe that universities are a place for discussion and dialogue, not for reporting people to security agencies (Quraishi, 2016). In order to succeed, this needs cooperation between the community, the government workers, and civil society; however, finding early signs of radicalization could not be attained without some innocent people mistakenly referred to police on the ground of terrorism (Lee, 2012). As a result, the government reviewed this strategy and acknowledged that there were some flawed and incorrect practices such as the excessive pressure placed on education institutions regarding the referral process. In addition, the government suggested changing the name of the program to reflect more transparency and engagement with communities. 
Moreover, the Prevent program has reached almost all tiers of the state, which could be unique to the UK; even education institutions were ordered to report on people at risk of extremism. Many first respondents do not know what extremism is or how to detect radicalization among students.

Shami Chakrabarti criticizes the strategy, calling it a spy agency aimed at collecting information about Muslims (Casciani, 2010). Prevent is also stigmatized as a tool to deny Muslims freedom of expression and will increase Islamophobia (Quraishi, 2016). In 2015-16, about 7,500 referrals were made to the program, but no action was taken in $37 \%$ of the cases. In the ideology referral cases, one in every ten cases is from far-right extremism, and in some areas of UK far-right has exceeded the number of Islamists (Bbc, 2017). Although many Muslims in the UK have opposed the program, there is no evidence that the majority do: 50,000 individuals and almost 400 mosques voluntary have participated in these programs (Greer \& Bell, 2018).

\section{Successfulness}

While the Prevent program has been controversial, the government said that its program had stopped 150 people from traveling to Iraq and Syria (Bbc, 2017). It also claimed that the program reached almost 42,000 people in 2015-16. However, the government has not explained whether this reaching means effectiveness or just people knowing about it.

Thomas described the program as both failed and friendless, because it focuses on a Muslim minority only and endangers the cohesion of the community. He accused the program of practicing surveillance on Muslims and trying to engineer a change in Muslim values (Thomas, 2010). The criticism of Prevent is that it doesn't incorporate the Muslim community at the local government level.

The Quilliam Foundation has presented a paper for the Cameron government and indicates that CONTEST2, the new version of the counter-violence strategy, has expanded from the violent extremists to targeting non-violent extremism. The paper also noticed the lack of knowledge in Islam of first respondents (Rabasa, 2010).

Like other deradicalization programs, most of the evaluation of success came from a government body which increases the uncertainty of the program. In addition, the Prevent program like any other program observes a change in human behavior, which cannot be measured in a short period - it is dealing with issues needing a long time to change.

\section{Underlying Rationale}

The UK has widely applied early intervention strategy on counter violence where all government agencies and private entities should report on radicalization, so this strategy opens the door for marginalizing certain individuals depending on their beliefs and expression. It is noticed that Britain, unlike other countries, intervenes before radicalization occurs to deal with it as an early sign of violent extremism. However, this could generate many implications at all stages. Not only will it collide with freedom of expression protected by the constitution but also the early intervention mechanism has not been understood by the frontline workers which creates implication at the micro-level (Government of the UK, 2015). The counter-terrorism strategy for 2017 indicated legal measures should be taken if extremist views have been expressed in government and private institutions such as schools (Godec, 2017). Schoolteachers, for example, have a statutory duty to report on any student they believe might be prone to radicalization (Hooper, 2015).

The role of religion in the Prevent program has raised some severe issues such as that the government intervenes to shape some political views or it is changing the religious attitudes. The most important of these is that authorities support some strands of Islam over other strands. Ali emphasizes that the government neither aimed at changing the religious beliefs of individuals nor sided with a sect of Islam against another sect. He argues that the program challenges the participants to rethink some Islamic issues which were already challenged by Muslim scholars (Ali, 2015, p. 8). Kundnani, on the other hand, accuses the government of supporting some sects of Islam over others, such as Sufi over Sunni Islam (Kundnani, 2009).

One important aspect is that the Channel program's main concern is the vulnerable people or individuals at risk of radicalization. This, in turn, raises tough questions: How can frontline workersand police recognize those vulnerable people? Or what are the signs that make people prone to radicalization? (Bilazarian, 2016). The UK has addressed only the root causes of radicalization that served the goals of the programs. For example, it chose to neglect the marginalization of Muslim communities and socio-economic factors that lead young people to embrace terrorism. This leads us to think about the correlation between deradicalization programs and root causes of terrorism in specific contexts. Unfortunately, many programs do not reflect the real root causes; instead, they reflect government policy (Kundnani, 2009).

Although the UK program is unique in the West in that it is working closely with Muslim minorities and use Islamic content, it was built on the social context. Commander Dean Haydon, head of the London Metropolitan Police counterterrorism command, states that "work is done around cohesion, social integration, and engagement with civil society and the political system" (Silva, 2017). 
The UK strategy after 2010 has used funding of the programs as a tool to scrutinize the partners from Muslim communities against certain Western values which indicates that the Islamic content used in the program was not intended for deradicalization (Gwen Griffith-Dickson et al., 2014).

In summary, the British programs are closer to using ideology than other programs by incorporating Muslim organizations in the early intervention strategy. However, the government is using only what fulfills its targets without really addressing the underlying causes of radicalization. In addition, it made a mistake by supporting some sects over others in communities which are vulnerable and sensitive to such division.

\section{Case Study 3}

\section{Denmark}

The country's population is 5.8 million; $4 \%$ are Muslim, most of them from the first generation of Muslim immigrants (live population, 2017). Radicalization and foreign fighters have caused an increasing cultural divide between Muslims and the other communities of Denmark (Rabasa, 2010). This dispute peaked when a publication by the newspaper Jyllands-Posten had a cartoon depicting the prophet of Islam in a wrong manner, which upset not only the Muslims in Denmark but also in the wider Muslim world - Danish products were boycotted as a response (News, 2015).

In 2009, the government published its first counter-extremism plan called A Common and Safe Future: An Action Plan to Prevent Extremist Views and Radicalization among Young People (Government of Denmark, 2009). Although the document has acknowledged that the researchers have not yet agreed on the root causes of radicalization, it has identified identity and sense of belonging in youth as the most important causes of radicalization (Government of Denmark, 2009, p. 8). It also refers to international ideology as one of the root causes of terrorism. Denmark is including other groups besides Islamic extremists in its counter-extremism strategy, which is more apparent than in the UK; for example, left-wing and right-wing extremists. The country tries to distance itself from being stigmatized as anti-Muslim; in fact, it's clear from the strategy that most of its efforts and initiative are directed towards Muslims. In addition, the religious and theology debates with extremists are not an option in its policy. However, it works with the community, in general, to strengthen social cohesion rather than teaming up with Muslim representatives. Additionally, the government has initiated a program called 'Deradicalization - Targeted Intervention' (Government of Denmark, 2009) aimed at the radicalized people who have not violated the law. It is like many other European programs in that it is voluntary and applies crime prevention mechanisms.

Denmark is ranked as having the second-highest number of foreign fighters per capita from Europe in Syria and Iraq (Escritt, 2016). Unlike other European countries, it has given the returnees a second chance through rehabilitation. Until January 2017, 135 Danish individuals left the country to Iraq and Syria to fight with terror groups (Counter Extremism Project, 2017). Jacob Bundsgard, mayor of Aarhus, a city where the soft approach established, said that the returnees deserve a second chance to be integrated into the community (Higgins, 2014). The chief of police for the region, also noted that "what we are doing is working well, he added that "our program works as crime prevention, though full deradicalization is extremely difficult"(Higgins, 2014).

In August 2015 the Copenhagen Anti-Radicalization Task Force presented an 'Action Plan' to Copenhagen municipality, which suggested close dialogue and relation with the religious community and strengthening citizenship through schoolchildren's education and community engagement. The plan, which was framed as four years, suggested decreasing to a minimum the number of people who support Sharia Law. However, Hizb ut-Tahrir led a meeting dubbed 'Proud of Sharia' and wrote on his website that Denmark politicians have never stopped attacking Islam values and this plan was no exception (Counter Extremism Project, 2017).

\section{Mechanism}

In the Aarhus program, the aim is to prevent extremism and offer an exit opportunity for extremists to reject violence (Bertelsen, 2015). The early intervention is designed to help people at risk of radicalization, especially the youth. The exit part of this program is to help people who are already radicalized or returned from overseas but have not committed an offense (Bertelsen, 2015). The returnee should be screened first by the police with help from the domestic security service, known as P.E.T. However, none of those screened has been arrested; instead, they have been offered mentors to clarify the difference between Islam and militancy (Higgins, 2014). The mentors are not limited to religious people - they can be anyone deemed trusted by a detainee; they might be family or friends. The rationale of not jailing the returnee is that they might get exposed to more radical views in prison, which leads to more implications on a societal level (Higgins, 2014).

There are three important features associated with the Aarhus program: close cooperation between several longstanding institutions and authority to help people at risk of radicalization, social inclusion, and a scientific basis. It is based on preventing any outlaw activities and is not directed to any group or minority. 
Bertelsen stated that the program is organized as the SSP initiative (the SSP is an interdisciplinary collaboration between Schools, Social authorities, and Police aimed at crime prevention) and added that SSP has operated in the country for 40 years now (Bertelsen, 2015).

The exit part of Aarhus program, on the other hand, is dealing with people who have radical views in regards to community and Western democracy. The Exit program provides help and support to men and women who want to abandon violence and go back to normal life. The authorities deal with the returnees case by case and determine the proper process to deal with everyone. As a result of the first assessment, the participant receives help such as employment, peers, school work, psychology, housing, healthcare, and education.

Some argue that although the program is giving a brighter picture of diversity, it looks like the UK model where social workers, teachers, and first respondents became police informants. The BBC reported that school principals used to refer students to police when they noticed an extreme view (Mansel, 2015). The Aarhus program has more credibility than any other European program. This is partly because SSP has been working in the country for a long time so deradicalization and counter-violence programs work together, and this makes the people accept it more easily than, say, in Britain (Koehler, 2015, p. 139).

\section{Successfulness}

Assessing the successfulness of counter violent programs and policy in general and deradicalization, in particular, proves to be the most difficult in contemporary challenges (Sayed \& Barnes, 2015). Many reasons have been attributed to this, but the most important is that most of the researchers agree that these programs need a long time to see a result (Sayed \& Barnes, 2015). In addition, every participant in deradicalization programs has their way of denouncing the violence and resuming his normal life.

The Aarhus model has been considered by many researchers as successful because it was built on very long cooperation between schools, social workers, and police. However, only in the Danish context, the old run SSP programs are designed for the Danish people and could not be transferred to other countries (Koehler, 2015). The program is run by the police, making the credibility of the outcome undermined.

\section{Western Deradicalization Programs Assumptions}

\section{Introduction}

To determine what underlying assumption and scholarship lead the Western countries to establish deradicalization and CVE programs is a difficult task in many ways. First, the indications that these countries have built programs on solid evidence of root causes of radicalization are not clear. The logic behind that is simple: there are disagreements among researchers on the drivers of radicalization; consequently, the design of the programs has no clear vision on what to implement. Arab programs, on the other hand, have an ideology as a central driver, which makes their programs' objectives clear. Second, the government documents, which this study has scrutinized, give no clear evidence on the methodology of initiating these programs. Yet this study examines these documents to find out indications and evidence of how deradicalization programs have been approached. Finally, there is a gap between empirical research conducted by researchers in academic institutions and the way deradicalization practitioners conduct research.

Although foreign fighters and home-grown violent extremism are seen as a common challenge to Western countries, many European countries run their programs in regards to their needs, and they are different to other countries (Beers et al., 2016). This could be normal to some extent - Western countries are at variance with each other in terms of language, social-economic factors, minorities' size, culture, and many other variables. Despite this, the differences in state-level should not lead to differences in treating the root causes of radicalization at the individual level or micro level. Almost all root causes of radicalization in Western countries have significant similarities, even though the countermeasures to these causes are varied. The UK Prevent program, for example, is unlike the Aarhus in Denmark in terms of root causes of radicalization. While we find the Danish program emphasizes social inclusion and downplay religious perspective, we find Britain, on the other hand, gives weight to the role of religious leaders and Islamic organizations.

Additionally, the cooperation between the Western countries on CVE and terrorism issues is paramount. Not only have the governments recognized the importance of sharing intelligence and best practice, but academia and NGOs also share knowledge and new facts, which is rarely seen in Arab states. As a result, expert groups and specialized centers were established by the European Commission such as the International Center for the Study of Radicalization (ICSR) in London in 2008 (Koehler, 2017, p. 66). 


\section{Hearts and Minds}

Unfortunately, the CVE, counter-radicalization, and deradicalization efforts have not addressed the effects of ongoing events on the international scene that affect Muslim minorities in Western countries. The battle to win the hearts and minds of the Muslim minorities is seen by many researchers as the best approach to counter radicalization. But how can the Western countries win the hearts and minds of Muslim minorities while its military troops conduct military operations in Muslim countries?

For instance, Australia's participation in the war on terror campaign has increased the risk of terrorism and inflamed sentiments of its Muslims citizens, yet the government always denies this (Matthewson, 2016). In addition, the foreign policy of the West hinders the efforts of this approach. Terrorist groups also use the battle of hearts and minds to their advantage - they have benefited from the suffering of Muslims in Western countries (El-Said, 2015, p. 11). Denmark may represent a good example of this battle. The foreign fighters returnee have been given a second chance through participation in EXIT; the deradicalization program. Denmark also is different than the UK in that it does not punish people because of what they believe but what they do. According to rehabilitator Steffen Nielsen, "You can be alShabab all you like, as long as you don't actually do al-Shabab" (Counter Extremism Project, 2017).

Moreover, some CVE strategies, including deradicalization programs and anti-terrorism legislation, are counterproductive (Jarvis \& Lister, 2013). These could increase the fraction between minorities and law enforcement, which could lead to more extremism. For example, Prevent program in the UK was considered by many as a surveillance and intelligence tool rather than a counter-violence program (Bbc, 2017). Therefore, the Western government efforts to gain the hearts and minds of the detainees, people at risk of radicalization, families, and community leaders are insignificant. Despite this principle being of great importance, it was not reflected in the programs aimed at reducing the radicalization of communities.

\section{Religion, Security, and Democracy}

Using religious components in deradicalization efforts and programs in Western countries usually involves a great deal of debate and discussion. They exercise caution when it comes to the analysis of the affairs of its minorities and especially the religious, as developed countries intervening in religious matters in order to shape views could be considered undemocratic, a violation of human rights or violation of freedom of expression and speech. However, the UK counter-terrorism strategy has crossed the line and intervened in its minorities by two aspects; first, the then prime minister Mr. David Cameron acknowledged that the past tolerance strategy was wrong and it was time to act through supporting moderate mainstream voices. This diplomatic language means they will intervene in any minorities who do not follow Western values, including non-violent extremists. Second, the same strategy has identified the ideology as the leading cause of terrorism without differentiating between ideology and religion. It makes no effort to distance mainstream Muslims and the ideology of violent extremism, which puts all Muslims on the same level (Government of the UK, 2015). In addition, this strategy has not only tried to shape the politics of Muslim minorities but also it intervenes in the social affairs of Muslims such as divorce in Islam. Finally, the strategy asserts that the target of its programs is not only those who hold and support violent extremism but also the non-violent extremists.

Still, reasons are preventing Western democratic from widelysupporting the religious approach. The UK and Denmark, for example, have drawn mostly on a pre-AQ and pre-ISIS experience of other violent groups such as the IRA and neoNazis, so religion was not emphasized in these programs. In addition, the West istoo much focused on homegrown radicalization, and so the social aspects are more important. Finally, Western countries are unwilling to mandate correct Islam in democratic countries.

Indeed, the West applies double standards when it comes to discussing the role of ideology in deradicalization programs. On the one hand, they allow work to correct the doctrine of the non-religious extremists such as the extreme right-wing and neo-Nazis. On the other hand, they consider religious approaches in deradicalization as not democratic and a violation of freedom of expression (Koehler, 2017, p. 226).

As a result, striking a balance between the democratic burdens and the security requirements is difficult, and it could be a reason for program failure. Koehler asserts that without an active ideology component in any program, it will not be called a deradicalization program (Koehler, 2017, p. 85). Hamed El-Said also highlights using misunderstood and narrowly applied religious scriptures by a terrorist group to justify the violence, so using a counter-narrative needs religious content (El-Said, 2015).

\section{Identity and Belonging}

Searching for an identity by many young Muslims creates plenty of space for radicalization ideas (Rabasa \&Benard, 2014, p. 192; Seifert, 2010; Nasser-Eddine et, al., 2011). This indicates that the person is unsatisfied with their current situation or suffers exclusion. 
Therefore, when he or she joins a terrorist group, they became a new person in terms of name and alias, and for some, the change reaches into their hearts and minds which makes their inclusion in the group total and any deradicalization efforts seem useless. In Western Muslim communities, identity crises are more apparent in third generations who lost the connection to their parent's place of birth. Salafi Jihadist movements have been aware of this with Muslim minorities in the West and present an alternative under the term Umma (Mahood, 2017). This could lead some to radicalization narratives (Murshed \& Pavan, 2011). However, some researchers, such as Samuel Huntington and Bernard Lewis claim that Islam as a religion is incompatible with Western values and will collide with democracy (Murshed \& Pavan, 2011). Such a narrative is what Salafi Jihadist nourishes and feeds on in recruiting.

Have the Western deradicalization programs considered this factor when initiating the process? In fact, the Western governments have acknowledged the importance of identity and belonging in their counter violent extremism strategies; however, in executing the programs it is very sensitive publically, and other activities have been used to cover the reasons behind these activities. COMPACT programs in Australia have acknowledged social dynamics through many initiatives aimed at increasing communities' engagement and support. For example, sports competition, camps, mentors programs, cooking activities, and many other activities aimed at the inclusion of youth. Although the UK counter-terrorism strategy (2015) has stressed the importance of belonging, it was mentioned only three times without a practical plan (Home Department, 2015). On the other hand, the Netherlands in 2007 presented a project called Polarization and Radicalization Action Plan to integrate Muslim youth in the Dutch community, but unfortunately, this project was not renewed after 2011. It seems that the outcomes of these programs are difficult to measure, which gives some the belief they are useless.

\section{The Gap between Research and Practice}

Many Western countries have spent time and money on researching the causes of terrorism and radicalization to understand best and treat them. However, the application of these findings is seldom seen in practice by first respondents. In addition, training staff in dealing with a detainee in prison is an essential issue before implementing any program. Denmark has the best training of its staff in this scenario. The Channel program first-respondents learn how to deal with the sensitivity of some minorities. The research has demonstrated that unemployment, social exclusion, and lack of education and work opportunities are some of many examples of underlying factors leading to radicalization. However, these and other factors are underrepresented in CVE and deradicalization programs.

\section{Conclusion}

This chapter has sought to analyze deradicalization programs in Western countries in terms of the operation, scholarship built on an assumption behind adopting such programs. The chapter is doing so in order to fulfill one of the objectives of this study, which required a comparison between deradicalization programs in Arab states and Western states. Although these countries are different in language, geography, and size of the population, they have faced, to some extent, the same challenges of home-grown radical ideology and foreign fighters.

A detailed analysis of underlying assumptions reveals essential insights into these programs. Most importantly, though Western countries have denied intervention in the religious affairs of Muslim minorities, these programs are varied from each other in using religious content. While Britain has sought help from Muslim organizations and individuals, Australia has exercised caution in applying such concepts. Denmark, on the other hand, deals with terrorism as criminal activities to some extent. Additionally, social factors such as group dynamics, identity, and belonging are considered the most important part of radicalization causes. These countries have dedicated programs and initiatives to handle such grievances; however, most of these programs have suffered from unsustainable funding and lack of ability to be evaluated. To conclude, despite the importance of ideology in the radicalization process, addressing it was almost missing from most of these programs.

\section{References}

Affairs, Home. (2018). Countering violent extremism. Online: Home Affairs Government BodyRetrieved from https://www.homeaffairs.gov.au/about/national-security/countering-violent-extremism.

Akbarzadeh, Shahram. (2013). Investing in Mentoring and Educational Initiatives:The Limits of De-Radicalisation Programmes in Australia. Journal of Muslim Minority Affairs, 33(4), 451-463. doi:10.1080/13602004.2013.866347

BBC. (2017). Reality Check: What is the Prevent strategy? BBC. Retrieved from http://www.bbc.com/news/election2017-40151991 Retrieved from http://www.bbc.com/news/election-2017-401519914 June

Bilazarian, Talene. (2016). Countering Violent Extremism: Lessons on Early Intervention from the United Kingdom's Channel Program. Program on Extremism, 12. Retrieved from 
https://extremism.gwu.edu/sites/g/files/zaxdzs2191/f/downloads/Channel\%20CVE\%20UK.pdf Retrieved from https://extremism.gwu.edu/sites/g/files/zaxdzs2191/f/downloads/Channel\%20CVE\%20UK.pdfOctober,10

Brandis, George (2015). Combating Terrorist Propaganda Online. Online Parliment of Australia Government BodyRetrieved from http://parlinfo.aph.gov.au/parlInfo/search/display/display.w3p;query=Id\%3A\%22media\%2Fpressrel\%2F36698 $85 \% 22$.

Casciani, Dominic. (2010). "Prevent extremism strategy 'stigmatising', warn MPs". BBC. Retrieved from BBC.COM website: http://news.bbc.co.uk/2/hi/uk_news/8593862.stm Retrieved from http://news.bbc.co.uk/2/hi/uk_news/8593862.stm30 September

Cherney, Adrian. (2018). Evaluating interventions to disengage extremist offenders: a study of the proactive integrated support model (PRISM). Behavioral Sciences of Terrorism and Political Aggression, 1-20. doi:10.1080/19434472.2018.1495661

Government, NSW. (2018). Compact Program. Retrieved from http://multicultural.nsw.gov.au/communities/compact_program/

Hassan, Riaz. (2008). Social and economic conditions of Australian Muslims: Implications for social inclusion. Paper presented at the International Conference: Challenges to Social Inclusion in Australia: The Muslim Experience, , Melbourne

Higgins, Andrew. (2014, Dec,13). For Jihadists, Denmark Tries Rehabilitation. The New York Times. Retrieved from https://www.nytimes.com/2014/12/14/world/for-jihadists-denmark-tries-rehabilitation.html June,26

Hooper, Simon. ( 2015, Jul,23). Stifling freedom of expression in UK schools The UK Prevent programme infiltrates schools, targeting students who express certain views. [Press release]. Retrieved from https://www.aljazeera.com/indepth/features/2015/07/stifling-freedom-expression-uk-schools150721080612049.html

Houston, Cameron, \& Donelly, Beau. (2017, 7 June). Brighton terrorist blocked from deradicalisation programs. The Age Retrieved from https://www.theage.com.au/national/victoria/brighton-terrorist-blocked-from-deradicalisation-programs20170607-gwmjnj.html March,22,2018

Koehler, Daniel. (2015). Family Counselling, De-radicalization and Counter-Terrorism: The Danish and German programs in context. Countering violent extremism: Developing an evidence-base for policy and practice, 129138.

Levy, Ido. (2018). Deradicalization Programs in Australia and the Foreign Fighter Phenomenon. ict.org.il.

Mansel, Tim. (2015). How I was de-radicalised BBC. Retrieved from BBC.com website: http://www.bbc.com/news/magazine-33344898 Retrieved from http://www.bbc.com/news/magazine333448982 July

Matthewson, Paula. ( 2016,18 Jan). Turnbull on terrorism: It's not just the rhetoric that's changed [Press release]. Retrieved from http://www.abc.net.au/news/2016-01-18/matthewson-war-and-terrorism-turnbulls-new-approach/7095282

News, FOX. (2015,January 13). Muslim Boycotts Hurt Danish Firms [Press release]. Retrieved from http://www.foxnews.com/story/2006/02/16/muslim-boycotts-hurt-danish-firms.html

Quackenbush, Casey. (2017, December 21, ). A Timeline of Recent Terrorist Attacks in Australia. Time Retrieved from http://time.com/5075253/terrorist-attacks-australia-timeline/.March,21,2018

Quraishi, Fahi. (2016, 4 April ). Prevent gives people permission to hate Muslims - it has no place in schools. The Guardian. Retrieved from https://www.theguardian.com/commentisfree/2016/apr/04/prevent-hate-muslimsschools-terrorism-teachers-reject 24-03-2018

Ralston, Nick. (2017, 1 May ). Farhad Jabar captured giving Islamic State salute before Curtis Cheng shooting. The Sydney Morning Herald Retrieved from https://www.smh.com.au/national/nsw/farhad-jabar-captured-givingislamic-state-salute-before-curtis-cheng-shooting-20170501-gvwn36.html 21-04-2018

Review, World Population. (2018). United Kingdom Population. Retrieved from http://worldpopulationreview.com/countries/united kingdom-population/

Silva, Richard de. (2017). Is the UK counter extremism model working? Retrieved from Online https://www.defenceiq.com/cyber-defence-and-security/news/is-the-uk-counter-extremism-model-working

Thomas, Paul. (2010). Failed and Friendless: The UK's 'Preventing Violent Extremism' Programme. The British Journal of Politics \& International Relations, 12(3), 442-458. doi:doi:10.1111/j.1467-856X.2010.00422.x 